\title{
Model Efisiensi Mesin Sortasi Jeruk (Citrus nobilis) Tipe Rotasi dengan Pendekatan Analisis Dimensi
}

\author{
Budi Setiawan ${ }^{1)}$, Suhendra1)
}

1) Politeknik Negeri Sambas

Email : setiawanbudi5379@yahoo.com

Email : aka.suhendra@yahoo.com

\begin{abstract}
Abstrak
Jeruk Siam merupakan produk pertanian unggulan utama di Kabupaten Sambas, Kalimantan Barat. Saat ini, proses sortasi oleh petani dilakukan secara manual dengan kelemahan membutuhkan waktu sortasi yang sangat lama, sehingga menimbulkan persoalan saat panen raya. Untuk mengatasi masalah tersebut perlu dikembangkan cara penyortiran secara mekanis. Mekanisme penyortiran yang dipilih dan diteliti menggunakan mekanisme pengayakan dengan silinder berputar yang diberi lubang-lubang dengan diameter sesuai ukuran buah jeruk. Bidang sortasi pada permukaan dalam silinder dilengkapi dengan alur pemisah. Pendekatan analisis dimensi digunakan untuk memperoleh persamaan matematis yang dapat digunakan untuk memprediksi efisiensi penyortiran mesin. Variabel bebas mesin yang dianalisis adalah spherecity $(\Phi)$, massa jenis buah $(\rho)$, kemiringan bidang sortasi $(\theta)$, panjang lintasan bidang sortasi (L), kecepatan sortasi (v), massa input jeruk (m), diameter drum sortasi (D) dan lebar lintasan (j). Hasil simulasi efisiensi penyortiran dengan memvariasikan massa input menunjukkan hasil terbaik diperoleh pada massa input jeruk 2,12 kg dengan efisiensi penyortiran sebesar $68,24 \%$. Sedangkan dengan memvariasikan kemiringan bidang sortasi menunjukkan bahwa hasil simulasi terbaik diperoleh pada kemiringan bidang sortasi $10^{\circ}$ dengan efisiensi penyortiran sebesar $68,61 \%$. Persamaan yang diperoleh selanjutnya diverifikasi dengan cara membandingkan dengan data hasil pengujian. Analisis kesesuaian persamaan prediksi menunjukkan bahwa persamaan prediksi dapat diterima.
\end{abstract}

Kata kunci : Jeruk Siam, mesin sortasi, model efisiensi

\section{Pendahuluan}

Di Indonesia Jeruk Siam Pontianak (Citrus nobilis) dikenal memiliki warna kulit hijau kekuningan mengkilap dan warna daging ranum jingga. Dikenal sebagai komoditas andalan sejak awal tahun 80-an hingga sekarang, jeruk yang berasal dari Tebas, Kabupaten Sambas, Kalimantan Barat ini memiliki rasa manis yang khas.

Peningkatan ekonomi rakyat melalui pembangunan pertanian di Kabupaten Sambas makin meningkat dikarenakan sektor ini masih dominan. Hal ini terlihat dari diterbitkannya Keputusan Bupati Sambas Nomor 163 A Tahun 2001 tanggal 20 Juli 2001 tentang penetapan jeruk sebagai komoditas unggulan daerah Kabupaten Sambas. Sebagai konsekuensi dari peraturan daerah tersebut, seluruh komponen pemerintah daerah dikerahkan untuk mendukung suksesnya pengembangan agribisnis jeruk di Kabupaten Sambas. Dukungan tersebut berupa kebijakan dan penyediaan sarana fisik yang mendukung berkembangnya investasi dan ekonomi dari aktivitas agribisnis jeruk Siam Pontianak (Direktorat Jenderal Bina Produksi Hortikultura, 2003)

Karena sektor agribisnis jeruk mempunyai peluang besar untuk meningkatkan pertumbuhan ekonomi bangsa yang berdampak kedepannya kepada kesejahteraan masyarakat, maka Pemda Kabupaten Sambas menyediakan lahan seluas kurang lebih 11.000 hektar untuk pengembangan sektor agrobisnis jeruk (Animardik, 2006). Menurut Bappeda Kabupaten Sambas (2008), tanaman jeruk Siam yang telah berproduksi di Kabupaten Sambas mencapai 3.193.537 pohon dengan jumlah produksi 1.516.326 kwintal per musim. Jumlah ini setara dengan 42,25\% dari jumlah total produksi buah di Kabupaten Sambas.

Peningkatan luas lahan tanaman jeruk perlu diantisipasi dengan teknologi budidaya dan pasca panen yang lebih baik. Di bidang pasca panen, saat ini masih terdapat masalah yaitu pada saat panen raya, terjadi permasalahan dalam hal sortasi. Sampai saat ini, proses sortasi oleh petani masih dilakukan secara manual dengan kelemahan membutuhkan waktu sortasi yang sangat lama. Sortasi tersebut dilakukan dengan cara mencocokkan setiap buah jeruk dengan standar ukuran yang terbuat dari kayu. Upaya menghindari waktu yang lama, banyak dijumpai kasus sortasi yang dilakukan oleh petani hanya berdasarkan ketajaman mata dan pengalaman penyortir. 
Untuk mengatasi masalah tersebut diperlukan suatu perancangan dan analisis mesin sortasi jeruk yang diharapkan dapat membantu para petani jeruk maupun pengepul dalam melaksanakan usahanya.

Penyortiran secara mekanis dapat dilakukan menggunakan ayakan (screen) bentuk datar dengan sistem translasi atau ayakan bentuk silinder dengan sistem rotasi. Ayakan dibuat miring, dimana salah satu bagian dibuat tinggi dari yang lainnya dengan penggetar secara vertikal atau horisontal sangat efektif untuk menyortir biji-bijian atau benda yang berbentuk lingkaran (Henderson, 1976).

Sebagai pembanding, beberapa penelitian tentang sortasi telah dilakukan. Asmara (2006) telah melakukan penelitian pengaruh kemiringan rak sortasi terhadap hasil penyortiran buah duku, hasil penelitian menunjukkan bahwa kemiringan rak sortasi terbaik diperoleh pada sudut $20^{\circ}$ dengan jumlah duku yang tersortasi sempurna pada grade A adalah $72 \%$, grade B $64,68 \%$ dan grade C adalah $84 \%$.

Pusat penelitian kopi dan kakao (2004) telah merancang unit mesin sortasi kontinyu biji kakao tipe silinder berputar. Hasil pengujian menunjukkan bahwa kapasitas mesin optimal sebesar $1.246 \mathrm{~kg}$ per jam pada kecepatan putar silinder sortasi $16 \mathrm{rpm}$ dan kemiringan $5,4^{\circ}$. Biaya sortasi adalah $\mathrm{Rp} 26$ per $\mathrm{kg}$ atau turun 50 persen dari biaya sortasi secara manual penuh. Produktivitas sortasi manual meningkat dari $110,16 \mathrm{~kg}$ per orang per hari menjadi 213,76 kg per orang per hari.

Selain itu penelitian tentang mesin sortasi jeruk antara lain Suparlan et al. (2005) yang merancang alat sortasi jeruk dengan sistem elektronik dimana alat penangkap buah yang digerakkan oleh silinder pneumatik dan dikendalikan dengan PLC (programable logic controller). Hasil uji unjuk kerja diperoleh kapasitas mesin sortasi sebesar 581 butir/jam $(62,6 \mathrm{~kg} / \mathrm{jam})$ dengan tingkat keseragaman ukuran/ diameter buah hasil pemisahan sebesar $95 \%$.

Satriyo (2004) mengembangkan mesin sortasi buah jeruk tipe BSM-1 dengan memakai sensor timbangan yang dilengkapi dengan saklar sentuh. Alat ini mempunyai kapasitas penyortiran $427 \mathrm{~kg} / \mathrm{jam}$ yang diperoleh pada kecepatan putaran poros meja sortasi $7 \mathrm{rpm}$, efisiensi $90 \%$ dan hampir tidak ada kerusakan buah.

Penelitian ini dilakukan pada mesin sortasi jeruk dengan tipe rotasi berbentuk silinder berputar. Perancangan mesin sortasi jeruk Siam dengan sistem rotasi ini dibatasi pada variabel yang diperkirakan berpengaruh pada proses penyortiran jeruk yaitu massa input buah jeruk, kemiringan bidang sortasi dan kecepatan putar bidang sortasi.

Namun sampai saat ini efisiensi optimal dari mesin sortasi jeruk Siam dengan sistem rotasi ini belum diketahui. Padahal efisiensi dari suatu mesin yang dirancang sangat penting agar kita dapat mengetahui kinerja dari mesin tersebut dalam menjalankan fungsinya. Sehingga diperlukan penelitian yang bertujuan untuk menganalisis kinerja mesin guna mendapatkan persamaan matematis yang dapat digunakan untuk memprediksi efisiensi penyortiran jeruk pada mesin sortasi jeruk tipe rotasi berdasarkan berbagai parameter kerja mesin.

Hasil penelitian ini diharapkan dapat dimanfaatkan untuk menentukan parameter kerja mesin terbaik sebagai bahan pertimbangan dalam pengembangan rancangan mesin sortasi jeruk selanjutnya.

\section{Metodologi Mesin yang digunakan}

Penelitian ini dilakukan pada mesin sortasi buah jeruk tipe rotasi. Spesifikasi mesin dan komponen hasil rancangan disajikan pada tabel (1).

Tabel 1. Spesifikasi mesin uji hasil rancang bangun

\begin{tabular}{ll}
\hline \multicolumn{1}{c}{ Keterangan } & \multicolumn{1}{c}{ Spesifikasi } \\
\hline $\begin{array}{l}\text { Mesin } \\
\text { 1. Nama mesin }\end{array}$ & Mesin sortasi jeruk \\
$\begin{array}{l}\text { 2. Prinsip kerja } \\
\text { 3. Sumber penggerak }\end{array}$ & $\begin{array}{l}\text { Sistem rotasi } \\
\text { Motor listrik } 3 / 4 \mathrm{HP}\end{array}$ \\
\hline Komponen & \\
1. Dimensi alat & 170 x 56 x $109 \mathrm{~cm}$ \\
2. Rangka alat & Besi siku $4 \mathrm{~cm} \mathrm{x} 4 \mathrm{~cm}$ \\
3. Bidang sortasi & Plat stainless steel \\
& berdiameter $50 \mathrm{~cm} \mathrm{dan}$ \\
& panjang $122,5 \mathrm{~cm}$ \\
4. Hopper & Plat stainless steel \\
5. Penampung buah & Plat stainless steel \\
6. Sistem transmisi & Pulli dan sabuk-V \\
& \\
\hline
\end{tabular}

Pengujian mesin dilaksanakan di Laboratorium Energi dan Mesin Pertanian, Jurusan Teknik Pertanian, Fakultas Teknologi Pertanian, Universitas Gajah Mada Yogyakarta. Alat yang digunakan pada penelitian ini yaitu stopwatch, mesin sortasi jeruk dengan sistem rotasi, timbangan dan wadah. Bahan yang digunakan adalah buah jeruk Siam Pontianak (citrus nobilis).

Bidang sortasi dibuat terdiri atas 3 bagian yang disesuaikan dengan ukuran jeruk yang biasa terdapat dipasaran yaitu ukuran $\mathrm{AB}, \mathrm{C}$ dan 
D. Kode ukuran ditentukan berdasarkan surat keputusan Gubernur Kalimantan Barat nomor 106 tahun 1987 tentang standarisasi mutu buah jeruk Siam (citrus nobilis) produksi dari daerah Kalimantan Barat, dimana diameter buah jeruk adalah sebagai berikut.
a. Ukuran $A B$ : diameter $63-73 \mathrm{~mm}$
b. Ukuran C : diameter $56-62 \mathrm{~mm}$
c. Ukuran D : diameter 50-55 mm

Berdasarkan ukuran diameter buah jeruk Siam tersebut dibuat lubang-lubang pada bidangan sortasi yang diameternya menyesuaikan diameter buah jeruk. Untuk bidangan sortasi paling atas dibuatkan lubang untuk menyortir ukuran D, bidangan selanjutnya untuk menyortir ukuran $C$ dan bidangan yang paling bawah untuk ukuran $\mathrm{AB}$. Perlu dilakukan antisipasi apabila terdapat buah jeruk Siam yang memiliki ukuran diatas ukuran $\mathrm{AB}$ ( $\mathrm{AB}$ super), maka pada akhir bidangan sortasi akan dibuat tanpa lubang sehingga buahbuah lebih bebas untuk bergerak.

Bagian utama mesin sortasi jeruk tipe rotasi meliputi hopper, rangka, motor listrik, reducer, bidang sortasi dan saluran keluar.

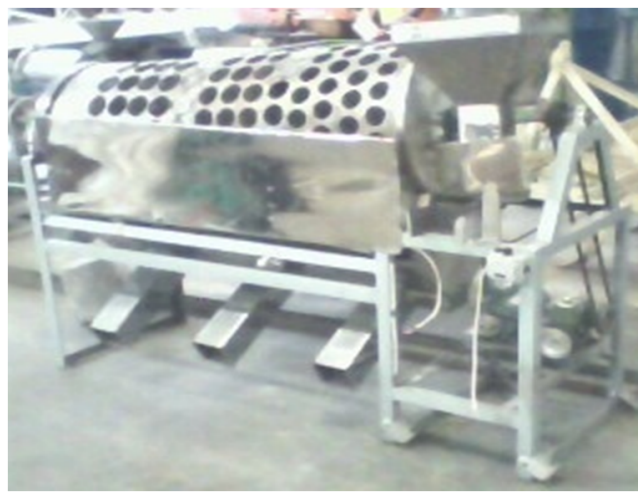

Gambar 1. Mesin sortasi jeruk tipe rotasi

Sebelum dilakukan analisis efisiensi penyortiran terlebih dahulu dilakukan pengujian pada mesin sortasi jeruk tipe rotasi hasil rancang bangun. Hasil ujicoba menunjukkan bahwa mesin yang dibuat telah sesuai dengan perancangan awal, namun terdapat beberapa hal yang ditemukan dalam operasional mesin antara lain adalah:

a. Buah jeruk menumpuk di hopper

b. Sebagian buah jeruk tidak memasuki penampung sesuai ukuran

c. Putaran bidang sortasi terlalu cepat

Buah menumpuk di hopper akibat bagian dasar hopper agak datar sehingga buah jeruk sulit untuk menggelinding. Solusinya adalah dengan membuat bagian dasar hopper lebih miring dari yang sebelumnya. Sebagian buah jeruk yang tidak memasuki penampung buah yang sesuai dengan ukurannya disebabkan karena letak lubang sortasi yang dibuat tidak sesuai dengan letak batas penampung masingmasing ukuran buah jeruk. Solusinya adalah dengan menutupi sebagian lubang sortasi. Putaran bidang sortasi yang terlalu cepat diatasi dengan menggunakan reducer dan puli.

Uji kinerja bertujuan untuk mengetahui pengaruh beberapa variabel terhadap kinerja mesin. Variabel mesin yang diuji adalah massa input buah jeruk, kemiringan bidang sortasi dan kecepatan putar bidang sortasi untuk menentukan nilai efisiensi $(\eta)$ sortasi mesin.

\section{Efisiensi $(\eta)$ penyortiran}

Variabel yang mempengaruhi efisiensi penyortiran adalah seperti yang ditunjukkan pada tabel (2). Penentuan variabel bebas berdasarkan perkiraan bahwa variabel-variabel tersebut berpengaruh terhadap variabel tak bebas. Dipilih massa jenis sebagai variabel bebas karena nilai massa pada massa jenis mempengaruhi inersia pada benda tersebut. Sedangkan dimasukkan spherecity adalah merupakan ukuran kemudahan bergerak buah pada bidang sortasi.

Tabel 2.Variabel yang mempengaruhi efisiensi penyortiran buah jeruk

\begin{tabular}{clccc}
\hline No. & \multicolumn{1}{c}{ Variabel } & Simbol & Satuan & Dimensi \\
\hline A & Variabel bebas & & & \\
& Bahan & & & \\
1 & Sphericity & $\Phi$ & - & - \\
2 & Massa jenis bahan & $\rho$ & $\mathrm{kg} / \mathrm{m}^{3}$ & $\mathrm{ML}^{-3}$ \\
& Mesin & & & \\
3 & Kemiringan & $\theta$ & - & - \\
4 & Panjang lintasan sortasi & $\mathrm{L}$ & $\mathrm{m}$ & $\mathrm{M}$ \\
5 & Kecepatan putar sortasi & $\mathrm{V}$ & $\mathrm{m} / \mathrm{s}$ & $\mathrm{LT}^{-1}$ \\
6 & Massa input jeruk & $\mathrm{m}$ & $\mathrm{kg}$ & $\mathrm{M}$ \\
7 & Diameter bidang sortasi & $\mathrm{D}$ & $\mathrm{m}$ & $\mathrm{L}$ \\
8 & Lebar lintasan silinder & $\mathrm{j}$ & $\mathrm{m}$ & $\mathrm{L}$ \\
\hline B & Variabel tak bebas & & & \\
9 & Efisiensi penyortiran & $\eta$ & - & - \\
\hline
\end{tabular}

Berdasarkan variabel yang mempengaruhi efisiensi penyortiran buah jeruk, maka dapat dituliskan fungsi efisiensi penyortiran sebagai berikut :

$$
\begin{aligned}
& \eta=\mathrm{f}(\theta, \mathrm{L}, \mathrm{v}, \mathrm{m}, \mathrm{D}, \mathrm{j}, \rho, \Phi) \\
& \eta^{\mathrm{a}} \theta^{\mathrm{b}} \mathrm{L}^{\mathrm{c}} \mathrm{V}^{\mathrm{d}} \mathrm{m}^{\mathrm{e}} \mathrm{D}^{\mathrm{f}} \mathrm{jg} \rho^{\mathrm{h}} \Phi^{\mathrm{i}}=1
\end{aligned}
$$

Berdasarkan ketentuan teori phiBuckingham maka persamaan tersebut ditransfer dalam bentuk notasi dimensi sebagai berikut: 


\section{$[0]^{\mathrm{a}}[0]^{\mathrm{b}}[\mathrm{L}]^{\mathrm{c}}[\mathrm{LT}-1]^{-1}[\mathrm{M}]^{\mathrm{e}}[\mathrm{L}]^{\mathrm{f}}[\mathrm{L}]^{\mathrm{g}}$}

$[\mathrm{ML}-3]^{\mathrm{h}}[0]^{\mathrm{I}}$

Selanjutnya dilakukan pemilihan kelompok variabel untuk mendapatkan nilai determinan lebih besar dari nol, sehingga diperoleh bilangan-bilangan tak berdimensi dibawah ini :

$\pi_{1}=\eta, \pi_{2}=\cos \theta, \pi_{3}=\left(\frac{L}{D}\right), \pi_{4}=\left(\frac{m}{\rho \cdot D^{3}}\right)$,

$\pi_{5}=\left(\frac{j}{D}\right), \pi_{6}=\phi$

$\pi_{1}$ merupakan fungsi $\pi_{2}$ sampai $\pi_{6}$ yang dinyatakan dengan :

$$
\eta=f\left[\cos \theta, \frac{L}{D}, \frac{m}{\rho D^{3}}, \frac{j}{D}, \phi\right]
$$

Dengan menganggap bahwa panjang lintasan (L), diameter bidang sortasi (D), dan lebar lintasan (j) adalah konstan, serta nilai spherecity $(\Phi)$ bahan uji dianggap seragam maka dapat diperoleh persamaan fungsi efisiensi penyortiran $(\eta)$ sebagai berikut :

$$
\eta=f\left[\cos \theta, \frac{m}{\rho D^{3}}\right]
$$

\section{Hasil dan Diskusi}

Tahap pertama dilakukan analisis hubungan antara parameter secara tunggal yaitu antara parameter $\pi_{1}$ dengan $\pi_{2}, \pi_{1}$ dengan $\pi_{3}$ dan $\pi_{1}$ dengan $\pi_{4}$.

Persamaan prediksi akhir efisiensi penyortiran pada mesin sortasi jeruk tipe rotasi diperoleh dengan terlebih dahulu melakukan logaritma terhadap nilai $\pi$, dilanjutkan dengan regresi linier berganda dan analisis antilog terhadap data yang diperoleh. Dari hasil analisis nilai $\pi$ diperoleh persamaan :

$$
\pi_{1}=0,152 x \pi_{2}^{0,979} x \pi_{3}^{-0,376}
$$

Dengan mensubstitusikan variable-variabel utama kedalam persamaan diatas, diperoleh persamaan prediksi efisiensi penyortiran akhir yaitu :

$$
\eta=0,152 x(\cos \theta)^{0,979} x\left(\frac{m}{\rho D^{3}}\right)^{-0,376}
$$

Hasil simulasi efisiensi penyortiran dengan memvariasikan massa input pada mesin uji menunjukkan bahwa penambahan massa input buah jeruk cenderung akan menurunkan efisiensi penyortiran. Hasil simulasi terbaik diperoleh pada massa input jeruk 2,12 kg dengan efisiensi penyortiran sebesar $68,24 \%$.

Hasil simulasi dengan memvariasikan kemiringan bidang sortasi menunjukkan bahwa penambahan kemiringan bidang sortasi juga akan menurunkan efisiensi penyortiran hingga batas tertentu kemudian nilainya cenderung stabil. Hasil simulasi terbaik diperoleh pada kemiringan bidang sortasi $10^{\circ}$ dengan efisiensi penyortiran sebesar 68,61\% seperti yang ditunjukkan pada gambar 2 dan 3 dibawah. Dibandingkan dengan kemiringan bidang sortasi $10^{\circ}$ Sedangkan hasil simulasi dengan memvariasikan kecepatan putar bidang sortasi memiliki pengaruh tetapi tidak signifikan terhadap efisiensi penyortiran.

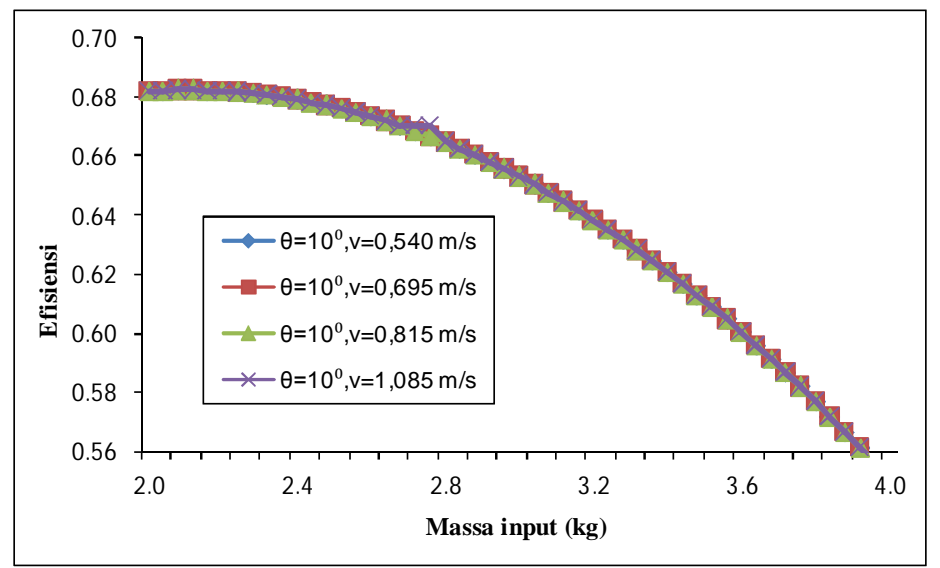

Gambar 2. Hasil simulasi persamaan prediksi efisiensi penyortiran dengan massa input jeruk yang bervariasi 


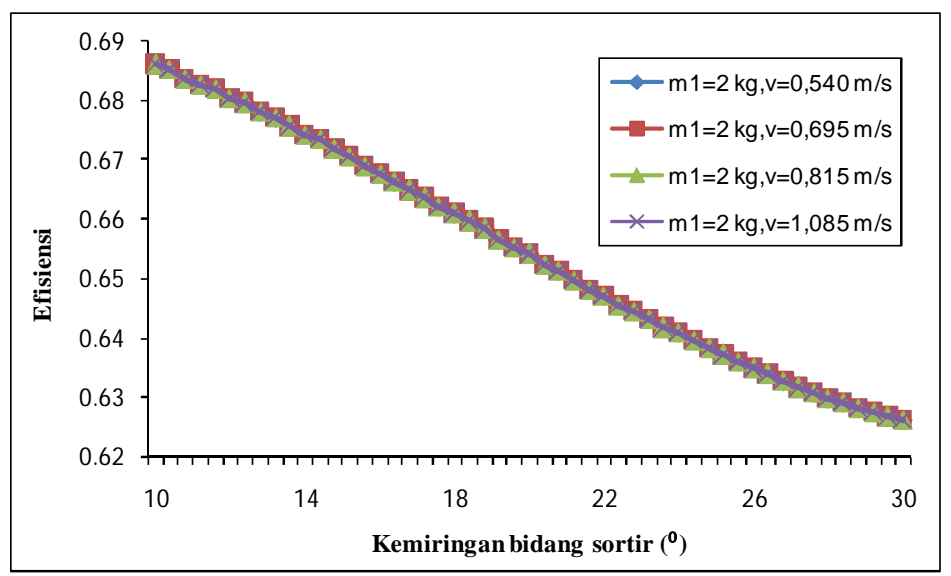

Gambar 3. Hasil simulasi persamaan prediksi efisiensi penyortiran dengan kemiringan bidang sortasi yang bervariasi

Hubungan matematis antara efisiensi penyortiran hasil observasi (Y) dan efisiensi penyortiran hasil prediksi (X) ditunjukkan dengan persamaan :

$$
\mathrm{Y}=0,799 . \mathrm{X}+0,117
$$

Dengan koefisien determinasi $\left(\mathrm{R}^{2}\right)=0,745$ seperti ditunjukkan pada gambar 4 .

Persamaan prediksi yang diperoleh tersebut berlaku pada batas nilai $\pi$ atau nilai variabel tertentu, sebagai berikut:

1. Nilai $\pi_{2}(\cos \theta)$ dari 0,87 sampai 0,98 atau kemiringan bidang sortasi dari $10^{\circ}$ sampai 30

2. Nilai $\pi_{3}\left(\mathrm{~m} / \rho . \mathrm{D}^{3}\right)$ dari 0,016 sampai 0,032 atau massa input buah jeruk dari $2 \mathrm{~kg}$ sampai $4 \mathrm{~kg}$.

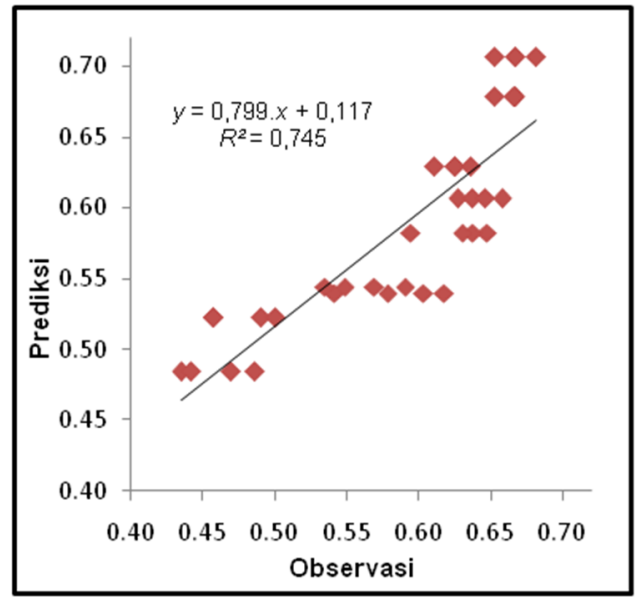

Gambar 4. Grafik perbandingan efisiensi penyortiran hasil observasi dengan hasil prediksi menggunakan persamaan (8)
Analisis kesesuaian persamaan prediksi efisiensi penyortiran mesin dilakukan berdasarkan uji t berpasangan (paired t-test) antara hasil observasi dengan hasil prediksi (Gomez dan Gomez, 1984). Hasil observasi merupakan hasil pengujian yang dilakukan pada mesin sortasi jeruk Siam dengan mengkombinasikan kemiringan bidang sortasi, massa input jeruk dan kecepatan putar bidang sortasi. Berdasarkan data dengan degrees of freedom $(\mathrm{df})=34$ dan $\alpha=0,05$, diperoleh nilai $t$ (nilai parametrik data rata-rata) dari tabel sebesar 2,032 sedangkan nilai $t$ hasil perhitungan diperoleh sebesar 0,873 .

Hasil perbandingan menunjukkan bahwa nilai $t_{\text {hitung }}$ kurang dari nilai $t_{\text {tabel }}(0,873<2,032)$, ini berarti bahwa persamaan prediksi efisiensi penyortiran yang telah dihasilkan tidak berbeda nyata dengan hasil observasi, sehingga bentuk persamaan akhir prediksi efisiensi penyortiran mesin sortasi jeruk tipe rotasi dapat diterima.

Persamaan prediksi yang dihasilkan selanjutnya dapat digunakan untuk mengatur kinerja mesin dengan menentukan parameter yang berhubungan dengan kinerja mesin untuk menghasilkan efisiensi penyortiran terbaik.

\section{Kesimpulan}

Analisis kinerja terhadap mesin sortasi jeruk tipe rotasi dilakukan dengan pendekatan analisis dimensi untuk mendapatkan persamaan matematis yang dapat digunakan dalam memprediksi efisiensi penyortiran mesin. Dari hasil analisis dengan variabel bebas berupa 
kemiringan bidang sortasi $(\theta)$, massa input jeruk $(m)$, massa jenis jeruk $(\rho)$ dan diameter bidang sortasi (D) menghasilkan efisiensi penyortiran mesin $(\eta)$ dengan persamaan berikut :

$\eta=0,152 x(\cos \theta)^{0,979} x\left(\frac{m}{\rho D^{3}}\right)^{-0,376}$

Persamaan prediksi diatas berlaku pada batas kemiringan bidang sortasi dari $10^{\circ}$ sampai $30^{\circ}$ dan massa input buah jeruk dari $2 \mathrm{~kg}$ sampai 4 kg. Dari hasil analisis kesesuaian menunjukkan bahwa pada batas keberlakuan, persamaan yang diperoleh dapat diterima sehingga dapat digunakan untuk memprediksi efisiensi penyortiran mesin.

Hasil terbaik simulasi efisiensi penyortiran diperoleh pada bidang kemiringan $10^{\circ}$ dan massa input jeruk $2 \mathrm{~kg}$ yaitu sebesar 71,07\%. Hasil simulasi ini dapat dijadikan rekomendasi dalam penggunaan mesin sortasi jeruk Siam dengan sistem rotasi.

\section{Pustaka}

Anonim, 2009, Badan Standarisasi Nasional, SNI No. 3165

Anonim, 2003, Profil Jeruk Di Kabupaten Sambas, Direktorat Jenderal Bina Produksi Hortikultura, Jakarta

Bappeda, 2008, Pemerintah Daerah Kabupaten Sambas

Budi Satriyo, Mesin Sortasi Buah Jeruk Tipe BSM1, Balai Besar Pengembangan Mekanisasi Pertanian, 2004.

Gomez, K.A., Gomez, A.A., 1984, Statistical Procedures for Agricultural Research, John Wiley \& Sons, United States of America

Henderson S. M, 1976, Agricultural Process Engineering, The Avi Publishing Company, Inc., Westport

Pusat Penelitian Kopi dan Kakao Indonesia, 2004, Unit Mesin Sortasi Kontinyu Biji Kakao Tipe Silinder Berputar, Jember

Sandi Asmara, Warji, Linda, 2006, Pengaruh Kemiringan Rak Sortasi Terhadap Hasil Penyortiran Buah Duku, Seminar Nasional Mekanisasi Pertanian
Suparlan, Tjahjohutomo Rudy, Supriyanto, Widodo Puji, 2005, Penelitian dan Pengemb. Alsin Penanganan Segar Buah Jeruk dan Mangga, Balai Besar Pengembangan Mekanisasi Pertanian

Surat Keputusan Gubernur Kalimantan Barat Nomor 106 tahun 1987, Tentang Standarisasi Mutu Buah Jeruk Siam Produksi Dari Kalimantan Barat. 